\title{
Mercury and gold mining in Colombia: a failed state
}

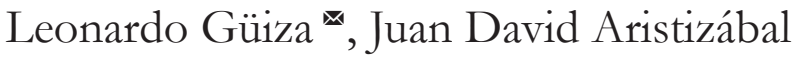

\begin{abstract}
Identifying and analyzing the causes and consequences that generate the high consumption of mercury in gold mining activities is an international priority. In Colombia, eighty-seven percent of the country's gold mines have no mining title and only $3 \%$ possess environmental licenses. High mining and environmental lawlessness, the failures of formalization programs and the inadequacy of importation controls on the supply are the cause of the high consumption of mercury in Colombian mining. To diagnose the country's gold mining activities and the excessive use of mercury in them, we used six information sources (semi-structured interviews, 2011 Census on Mining Activities), nine dependent and 21 independent variables. The study evidenced the miners' partiality in favor of the use of mercury in the procurement of gold; the process is easy, quick and inexpensive. Mercury concentrations were found to be above tolerable levels. In response, government has opted for a policy of persecution of the activity rather than the promotion of their formalization.
\end{abstract}

Keywords: Gold mining, mercury, informal mining, public policies

Grupo de Investigación en Derechos Humanos. Universidad del Rosario. Bogotá D.C. Colombia.
Colombia minera y uso de mercurio: un estado fallido. Resumen. Identificar y analizar las causas y consecuencias que están generando altos niveles de consumo de mercurio en la actividad aurífera es una prioridad internacional. Con el fin de hacer un diagnóstico de la actividad minera aurífera y del uso excesivo de mercurio en Colombia se usaron seis fuentes de información (entrevistas semi-estructuradas y censo minero 2011), nueve variables dependientes y 21 independientes. El 87\% de las minas auríferas del país no tenían título minero y sólo el 3\% contaba con licencia ambiental. Se evidenció que los mineros prefieren el uso del mercurio para el beneficio del oro por ser un método fácil, rápido y económico. Las causas de los altos niveles de consumo de mercurio en la actividad aurífera identificados fueron: la alta ilegalidad minera y ambiental, el fracaso de los programas de formalización y la falta de control sobre las importaciones del insumo. Los estudios evidenciaron concentraciones de mercurio por encima de los límites permitidos. Ante esta situación el Gobierno se ha inclinado por una política de persecución a la actividad en lugar de fomentar su formalización.

Resumo. Identificar e analisar as causas e consequências que estão gerando altos níveis de consumo de mercúrio na atividade aurífera é uma prioridade internacional. $87 \%$ das minas auríferas do país não têm título mineiro e somente $3 \%$ conta com licença ambiental. Alta ilegalidade mineira e ambiental, o fracasso dos programas de formalização e falta de controlo sobre as importações de consumo são as causas dos altos níveis de consumo de mercúrio na atividade aurífera. Para diagnosticar esta atividade e o uso excessivo de mercúrio na Colômbia, usaram-se seis fontes de informação (entrevistas semi-estruturadas, censo mineiro 2011), nove variáveis dependentes e 21 independentes. Evidenciou-se que os mineiros preferem o uso de mercúrio para o benefício do ouro porque é um método fácil, rápido e económico. Os estudos evidenciam concentrações de mercúrio acima dos limites permitidos. Ante esta situação o Governo inclinou-se para uma política de perseguição à atividade em lugar de fomentar a sua formalização. 


\section{Introduction}

Gold mining has generated controversy in recent years due to its impact on the environment and on human health (Ali 2006). However, the gold market has been gaining prominence globally, causing the production of this resource to increase to over 2,500 tons in 2010 (British Geological Survey 2012).

Correspondingly, gold production in Colombia has increased by over $300 \%$ since 2006 ; its production now ranks fifth in Latin America, exceeding Chile's production but still below that of Peru, Mexico, Argentina and Brazil (British Geological Survey 2012). Today, the country produces about 54,000 kilograms of gold a year, mainly in the departments of Chocó (24.500kg), Antioquia (19.000kg) and Bolivar $(5.700 \mathrm{~kg})$, this represents $91 \%$ of the annual gold production in Colombia. The remaining $9 \%$ of production takes place mainly in the departments of Caldas, Cauca, Huila, Nariño, Valle del Cauca, Tolima and Santander (Ministry of Mines and Energy 2011). Moreover, the country's annual production is expected to increase significantly with the discovery of new mining areas in the Serrania de San Lucas (Bolivar). This region covers over 1.5 million hectares and is considered "the largest gold mine in Latin America". Also, areas in Colosa, located in the municipality of Cajamarca (Tolima), considered among the seven largest gold mines in the world (Idárraga et al. 2010).

One of the major impacts of gold mining is the use of cyanide and mercury during the ore beneficiation process to extract the gold. Modern and mechanized gold industries, however, use cyanide almost exclusively as serious health and environmental issues have done away with amalgamation using liquid mercury (Longsdon et al. 2001). As a result, countries such as Venezuela have completely banned the use of mercury in the mining activity.

However, it is small-scale artisanal mining that is responsible for $20 \%$ to $30 \%$ of the world gold production (UNEP 2005, Veiga et al. 2006) and the use of mercury to separate and extract gold from the surrounding gold bearing materials is the favored practice (Veiga et al. 2006). The use of mercury allows the individual miners to accomplish the entire process independently without entering into partnerships with other miners; mercury is easy to use, highly effective in the capture of gold, very accessible and easy to transport as well as cheaper compared to other methods (Telmer and Veiga 2009).

Artisanal mining can be small, medium or large scale, typically employing rudimentary and instinctive techniques and devoid of long-term planning, in other words, the conventional techniques of geological exploration, drilling, proven reserves, or engineering studies are not employed (Hinton et al. 2003, Veiga 1997). From a social standpoint, this type of mining is intimately connected with poverty and lawlessness; sometimes, it is the only means of livelihood, especially in rural communities where economic alternatives are vastly limited. In most cases, the resources necessary to process the corresponding concessions or mining rights are not available, much less, to implement techniques mitigation of environmental impacts (Hilson and Pardie 2006). Thereon, it is important to understand the difference between illegal and informal mining. Illegal mining refers to the exercise of an activity of exploration and exploitation of minerals without first obtaining the appropriate title, authorization or concession by the mining authorities (Chaparro 2002). Meanwhile, informal mining is a set of conditions in which some miners find themselves, this includes, in addition to their illegal status, deficiencies in environmental management, technical assistance, transfer and technological development, no access to health system and job security, and no participation in decision-making processes that affect them, or access to information and humane working conditions (IIED 2002).

In the artisanal mining beneficiation process mercury adheres to the gold to form an amalgam, which facilitates its separation from other minerals of no financial interest, this is called amalgamation. This is accomplished using mainly two techniques, each one releasing different quantities of mercury into the environment (Telmer and Veiga 2009, Hylander et al. 2007, Veiga et al. 2006). In the first technique, $100 \%$ of the material is amalgamated during the crushing, grinding and washing process; this method is considered the most polluting use of mercury, it requires 3 to 50 units of mercury to produce one unit of gold, on average about 5 units 
A

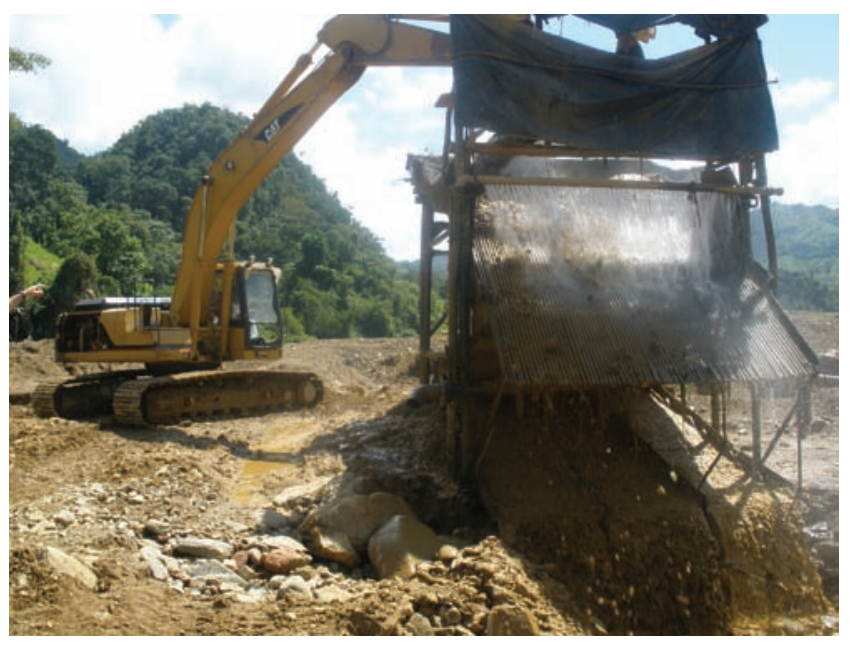

C

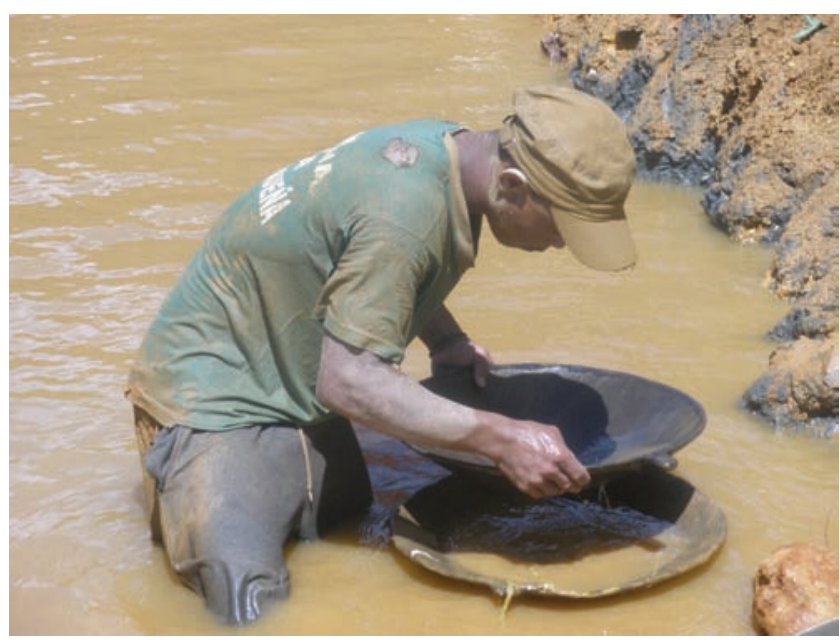

$\mathrm{E}$

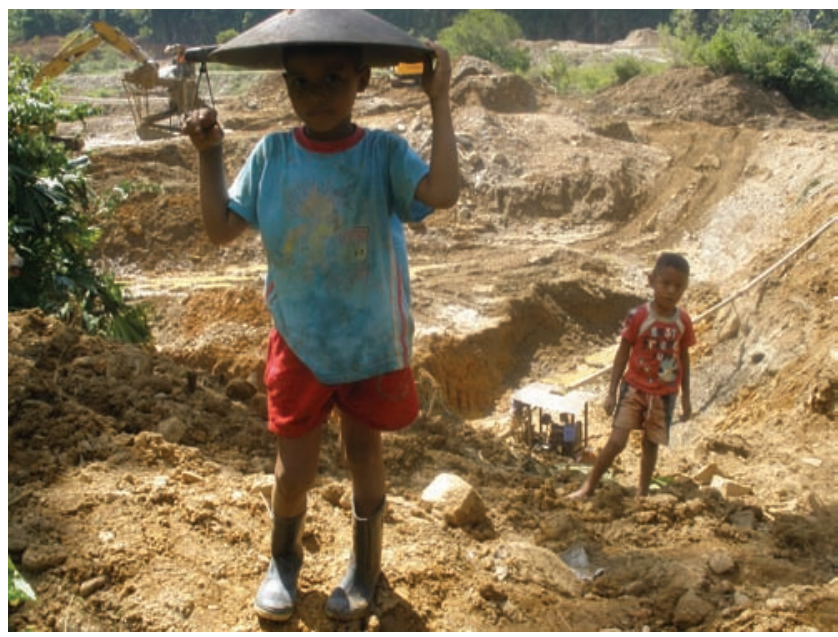

$\mathrm{B}$

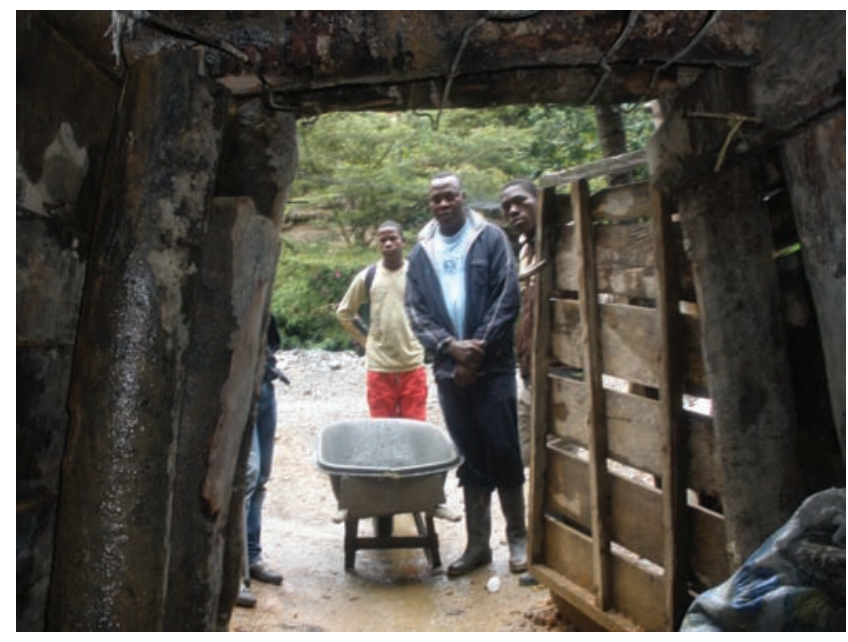

$\mathrm{D}$

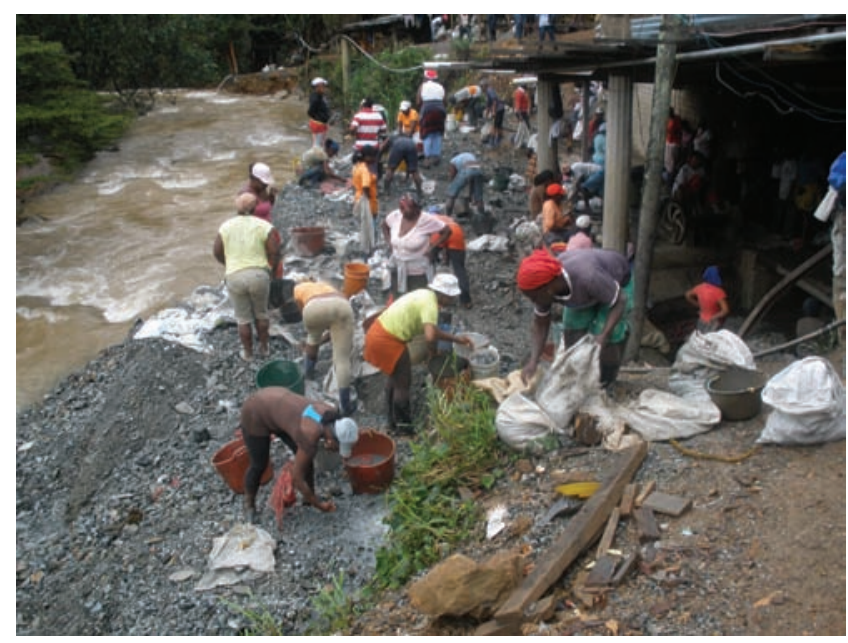

$\mathrm{F}$

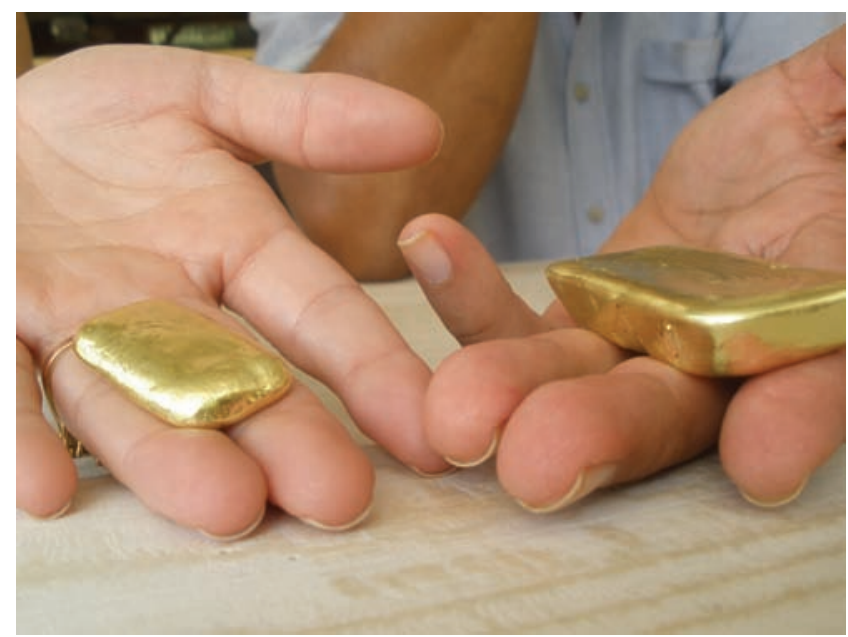

Fig. 1. Photographs of artisanal gold production in Colombia. A. Mechanized alluvial gold mining (Remedios, Antioquia); B. Shaft or underground gold mine (Buenos Aires, Cauca), C. Barequero (gold panner) working alongside a mechanized alluvial exploitation (Remedios, Antioquia); D. Women miners "chatarreras" (Suarez, Cauca); E. Children in the mines (Remedios, Antioquia), F. Gold bars after the amalgamation and roasting process (Remedios, Antioquia). 
are produced (Figure 1a).

It should be noted that only $10 \%$ of the material adheres to the amalgam in this process, indicating that if $10 \mathrm{~g}$ of mercury are used to produce $1 \mathrm{~g}$ of gold, $9 \mathrm{~g}$ of mercury are released immediately into the environment and $1 \mathrm{~g}$ remains in the amalgam. The second technique involves the screening or gravimetric concentration of gold bearing material whereby the auriferous mineral collects with the heavier particles in a pan and the water washes away the lighter particles (Figure 1c). Mercury is then added to the leftovers in the pan to unite or amalgamate the finest particles of gold. In this case, between 1 and 2 units of mercury is used to produce one unit of gold. In this process, $85 \%-90 \%$ of the mercury used adheres to the amalgamation. Once the amalgam (50\% gold and 50\% mercury) is obtained by any of the two previous processes, miners roast (heat) the amalgam to recover the gold. When done outdoors, $100 \%$ of the mercury from the amalgam is released into the atmosphere; therefore, the use of retorts is recommended to capture mercury vapor and recover up to $95 \%$ of reusable mercury. It is estimated that, globally, the use of these techniques discharges 1000 tons of waste mercury into the environment, $40 \%$ into the atmosphere and the remaining $60 \%$ are dumped on the soil and in the water (Pirrone et al. 2009, Cordy et al. 2011).

As mentioned, the mercury used to extract gold is highly polluting, it persists in the environment, it accumulates in food chains and it has damaging effects on human health (Liu et al. 2012). In its inorganic form, mercury can cause kidney damage, increased blood pressure, digestive tract problems and impact embryonic development as well as cause a disorder called acrodynia (EPA 2007). However, it is methylmercury, an organic form of mercury, which is the most dangerous because of its neurotoxicity. It can cause permanent brain damage, blindness, blurred vision, deafness, ataxia and death, and can cause mutations and malformations in the nervous system of fetuses (Eisler 2004, Liu et al. 2012).

Next to the combustion of fossil fuels, the production of gold generates the most mercury emissions. Mercury released into the atmosphere by the roasting of amalgam causes respiratory tract problems in the people who breathe it (Cordy et al.
2011). In spills, mercury is deposited directly into the soil or water bodies (Telmer and Veiga 2009). Mercury in the soil is absorbed by plants and makes its way to the fruits and seeds consumed by herbivorous species (Eisler 2004). In water, mercury is methylated by the bacteria in sediments producing methylmercury, which bioaccumulates along the food chain and accumulates, in high concentrations, in organisms that predate on fish (Liu et al. 2012). By consuming the fish contaminated with methylmercury or the plants grown from contaminated soils, humans become the final recipients of the mercury (Eisler 2004, UNEP 2005, Liu et al. 2012).

This is disturbing when you consider that Colombia is one of the major mercury importers in the world. Close to 130 tons were imported in 2011(Cordy et al 2011), 75\% of which was used in artisanal and small-scale mining (Telmer and Veiga 2009). Assuming that all national gold production uses mercury in the beneficiation process, we could roughly estimate, that if Colombia produces 54 tons of gold, we use $2.4 \mathrm{~g}$ of mercury is used to produce $1 \mathrm{~g}$ of gold, or double that if only half of the national production uses mercury in the beneficiation process. In comparison, it is estimated that $1.3 \mathrm{~g}$ of mercury is used to produce $1 \mathrm{~g}$ of gold in Brazil (Sousa and Veiga 2007) and in Central Kalimantan (Telmer and Stapper 2007). In these cases, $0.3 \mathrm{~g}$ of mercury are discharged into the water with tailings and coarse rejects and $1 \mathrm{~g}$ of mercury is emitted into the atmosphere when the amalgam is roasted. However, as we mentioned previously, the amount of mercury consumed per unit of gold produced varies substantially depending on how the process of amalgamation is performed (Telmer and Veiga 2009). As a result of these large imports, Colombia has emerged as the third largest producer of mercury emissions, between 50 and 100 tonnes per year (Telmer and Veiga 2008). In some municipalities of Antioquia, air emissions are in the order of $200.000 \mathrm{ng} / \mathrm{m}^{3}$ when the WHO recommended limit is $200 \mathrm{ng} / \mathrm{m}^{3}$ (Cordy et al. 2011).

These environmental impacts are inconsistent, however, with the Colombian legal system (Güiza 2011). To control the activity, the state requires two general requisites of mining operations: a mining title or mining concession (Law 685 of 2001 art. 14) and an environmental permit (Decree 2820 of 
2010 arts. 8 and 9). Additionally, environmental authorities require other specific authorizations to engage in mining activities, such as a water concession permit (Decree 1541 of 1978 art. 36), a forest resource use permit (Decree 1791 of 1996 art. 12) and a wastewater discharge permit (Decree 3930 of 2010).

In view of this, the need to identify and analyze the causes and consequences compelling the elevated use of mercury in auriferous activities becomes apparent. This need was intrinsic in the objectives of an interinstitutional accord between the Office of the Ombudsman and the Universidad del Rosario to establish a baseline and analyze various mining conflicts impinging on human rights in Colombia. Expanding on this, this paper presents the results and discussion in three parts. The first part, deals with mining and environmental informality and illegality in mining activities in the country. The second describes and analyzes the public policies and state management against illegal mining and the use of mercury; and the third, presents the results of the review of scientific literature on the environmental impacts on human health and the indiscriminate use of mercury in mining.

\section{Materials and Methods}

This article is the result of an investigation supported by the Colombian Ombudsman's Office, during its execution we accessed information provided by municipal mayoral offices and national mining authorities regarding a line of research focused on mining conflicts in Colombia. Six sources of information were considered during data collection:

1. Semi-structured surveys sent from the Ombudsman Office to the mayors of the municipalities with the strongest gold mining tradition in the country (Suppl. 1). In total, information was requested from 110 of the 1,119 municipalities in Colombia (10\%) and prioritized by the number of mining units by municipality according to a previous study sponsored by the same entity (Güiza 2010). By the cutoff date of July 13, 2012, 54 responses (50\% of the sample) were received from the total number of requests issued.

2. Semi-structured verbal survey conducted between December 2012 and January 2013 with three leaders of small traditional gold mining groups in three Colombian municipalities (Suppl. 2): Taraira in the department of Vaupés, Suárez in the department of Cauca and Remedios in the department of Antioquia. These leaders provided information on the use of mercury in the activity, the efficiency of mercury in the amalgamation process, the costs of using mercury versus the cyanidation method and the average monthly salary of a gold miner. These individuals were selected based on their acquaintance with the activity and therefore a more significant sample is not required since they are not reporting on the conditions of each individual miner, rather on the most general conditions of the activity.

3. The National 2011 Census on Mining Activities, obtained by the Ombudsman's Office from the Ministry of Mines and Energy. This census collected information on 14,357 mining units or mines, both legal (with mining title) and illegal (without mining title), and analyzed 323 variables for each mine (Suppl. 3). This information was submitted on May 25, 2012.

4. A review of current national standards on mercury use permissibility in gold mining in Colombia. To locate these standards, an examination of databases belonging to Notinet and the Secretary of the Senate of the Republic of Colombia was conducted between October and December 2012.

5. A probe of online news to determine the number and the location of security forces operations to close illegal gold mines and prosecute their employees. We compared news reports of raids during the second term of President Álvaro Uribe Vélez (August 2006-August 2010) and reports of operations carried out by the government of President Juan Manuel Santos (August 2010-August 2014). The search was achieved using Google, the descriptors used were: operations, illegal mining, confiscation, gold, Colombia, and mine closures. Additionally a news page filter was used.

6. A review of scientific literature on studies carried out in Colombia indicating the impacts of gold mining related mercury pollution on the environment and on human health. Several documentary sources were used to locate the bibliographical documents. The search was conducted between November and December 
Table 1. Matrix of variables and categories used in the study. General objective: identify and analyze the causes and consequences that are generating high levels of consumption of mercury in gold mining in Colombia.

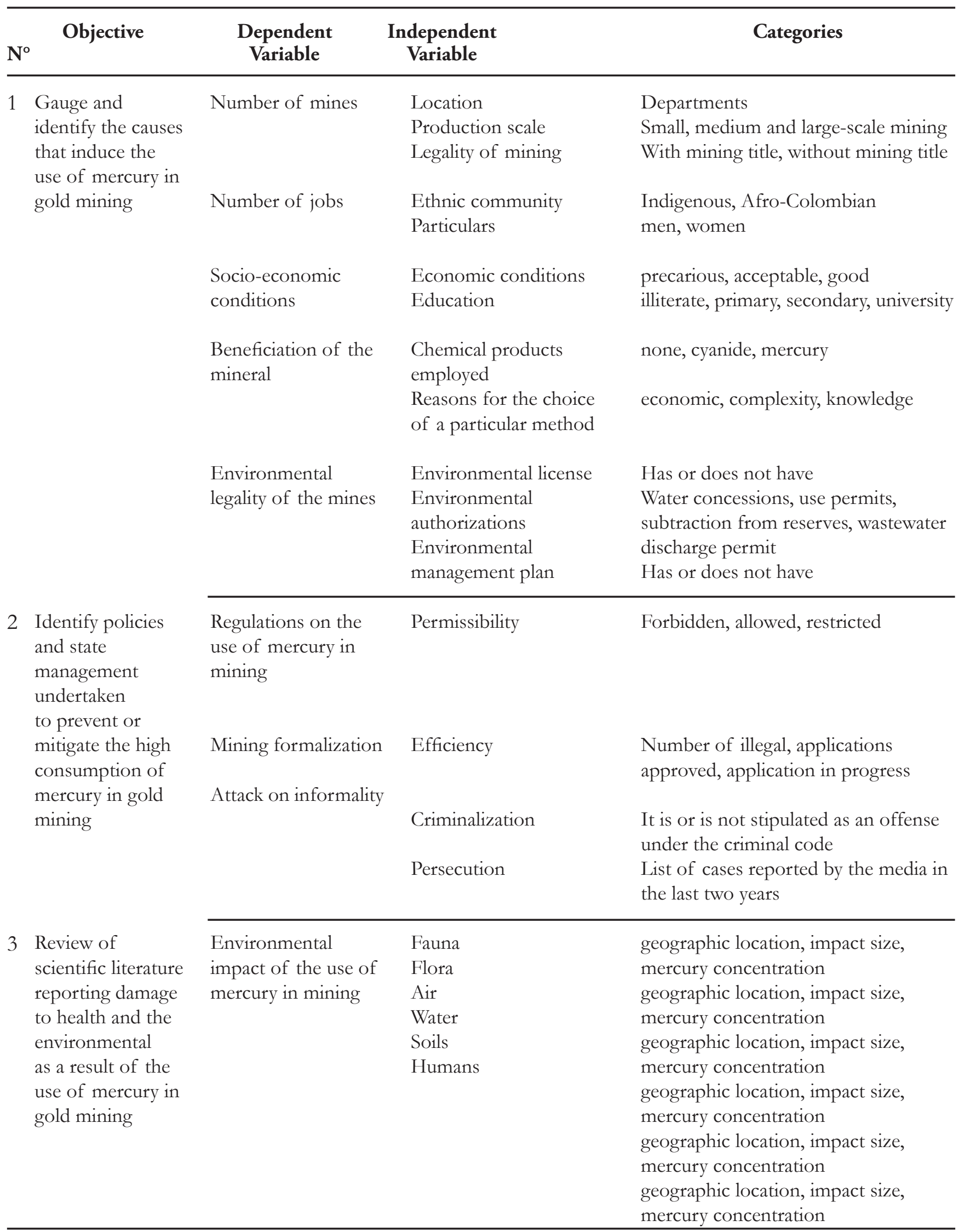


2012 in Scopus, ISI and Redalyc using the following descriptors: gold mining, artisanal mining, mercury pollution, small-scale mining, collectively combined with the word Colombia. We obtained between 4 and 49 logs after combining the different keywords. We also performed an Internet search using the "Google Scholar" search engine and using the same key terms.

The variables analyzed using these sources and their respective categories are presented in Table 1.

The processing of the results was performed using the triangulation between the analysis of the information obtained from the three previous items, the analysis of public policies and legal instruments governing the issue and the studies found in the literature review.

\section{Results}

Mining and environmental informality and illegality: According to the census of mining activities conducted in 2011, there are 4,134 gold mines in Colombia; 550 of these mines have the appropriate mining titles and 3,584 do not. This means that $87 \%$ of gold mining in Colombia is illegal or, according to Colombian mining laws, lack the corresponding mining title duly registered with the National Mining Registry (Law 685 of 2001, art. 14). Figure 2 shows the preponderance of gold exploitation in northeastern Colombia and along the Cordillera Occidental (western mountain range). Seventy-two percent of these mines are located mainly in the departments of Antioquia, Bolivar and Chocó and 94\% of them are illegal operations. On the other hand, gold mining operations with a mining title $(13 \%)$ are located predominantly in the departments of Antioquia, Huila, Caquetá, Santander and Norte de Santander (Figure 2).

Although mining legislation in Colombia does not distinguish or provide a stratification based on the size of mining operations, for academic purposes, we will classify them into three mining production scales: small, medium and large-scale mining. The only legal definition available is for small-scale mining, which refers to shallow mines, created with ordinary, manually operated tools and implements, powered by human strength and whose

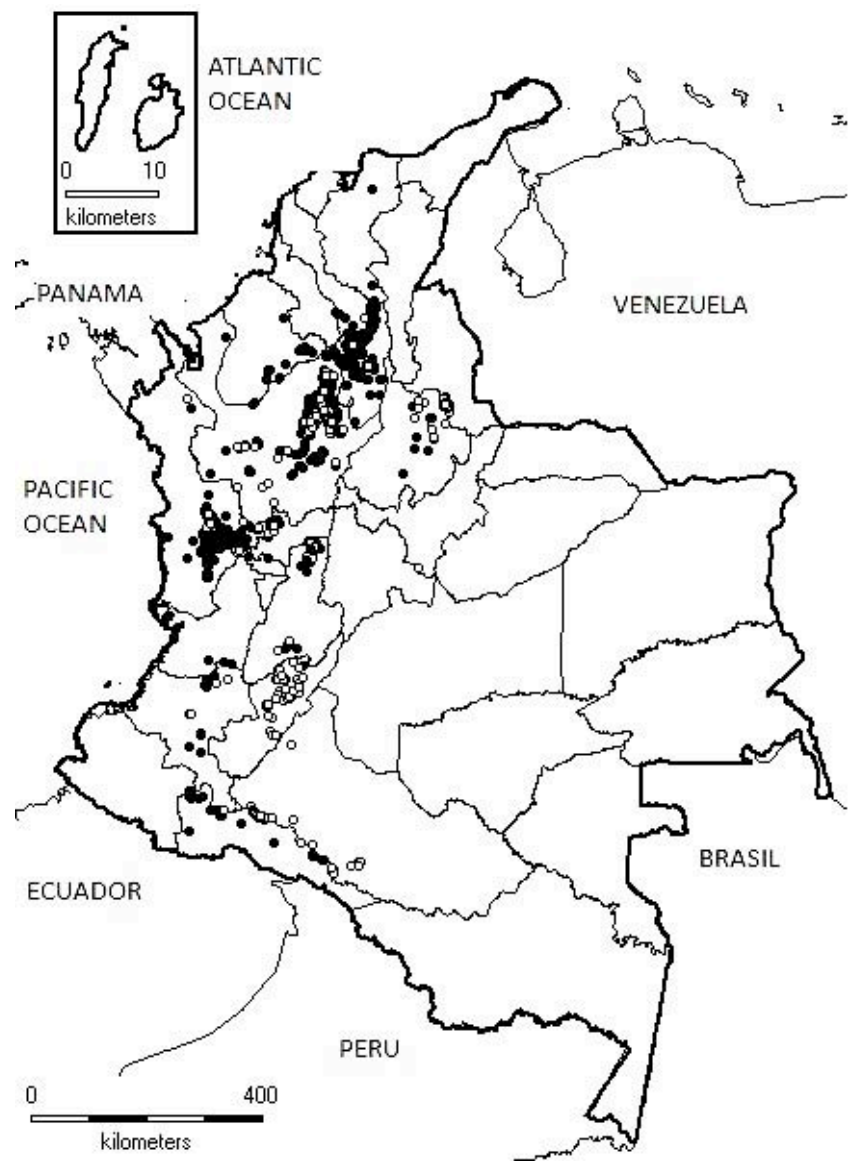

Fig. 2. Gold Mines in Colombia in 2011. ${ }^{\circ}$ : With mining title (legal). •: Mining w/o title (illegal). The highest density of points is found in the Cordillera Central and Occidental (central and western mountain range), also where the largest population in the country resides.

production does not exceed two hundred fifty (250) tons of material (Mining Technical Glossary 2003). In fact, according to the census of mining activities, most gold mining operations in Colombia are smallscale (2,815 mines) operations; they represent about $70 \%$ of the country's gold exploitation. Followed by medium-scale mines with 1,275 mines and lastly large-scale mines with only 44 in the entire country. Illegal exploitations predominate in both smallscale and medium-scale mining, whereas legality predominates in large-scale operations (Figure 3).

According to the census, gold mining generates 49,889 jobs; 39,824 are provided by illegal mining (80\%); while legal mining contributes 10,065. Similarly, the participation of ethnic populations in these activities is high, with more than $10 \%$ of the jobs occupied by these communities: 6,207 AfroColombians and 596 indigenous peoples. In total, 


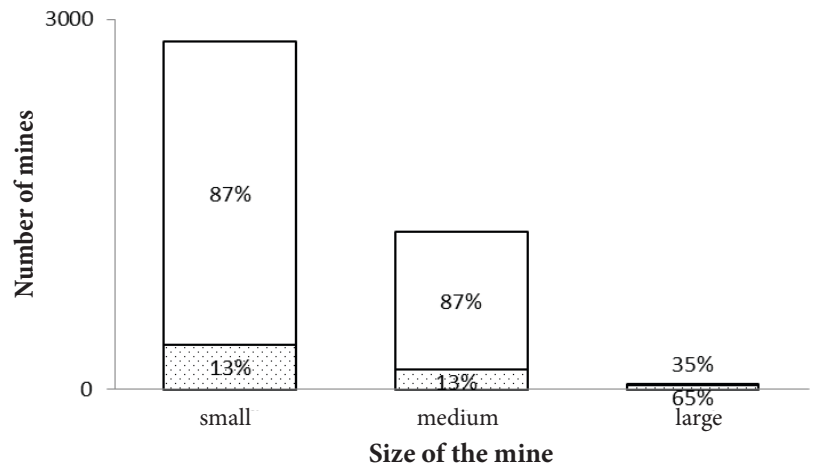

Fig. 3. Size of gold mines in Colombia. Empty areas: Number of illegal mines, Dotted areas: Number of legal mines. Relative percentage of mines presented within each category.

2,417 women work in this activity (Figure 1d) and 137 children (Figure 1e). As reported by mining leaders, a miner can earn between $\$ 500$ and $\$ 3,000$ a month depending on the mine's production level and considering that many of these workers are subcontracted and not direct employees.

Moreover, according to information provided by the municipal mayors, socio-economic conditions of artisanal miners in Colombia are precarious. Typically, this population is essentially rural, with a low level of education, low socioeconomic status and poor coverage by state social programs. According to the mining census, 64\% of gold miners completed only primary school education and $20 \%$ of them are illiterate.

Regarding predilection between the use of cyanide and mercury in the beneficiation of the mineral, the data obtained from interviews with mining leaders confirmed that the use of mercury is preferred to cyanide for various reasons. Firstly, building a cyanidation pool or tank can be a large and risky investment because the activity is clandestine and persecuted, if found out, the authorities may order the overnight closure of the mine. According to the miners, building a $4 \mathrm{~m}^{2}$ cyanidation tank, in present day, can cost around US $\$ 6,000$, a high price for small miners. The leaders also contended that mercury yields more than cyanide, making its use more cost-effective and that of mercury amalgamation and it is performed in a shorter time. According to the leaders, illegal alluvial gold mining (Figure 1a) is essentially nomadic and as a result building cyanidation ponds is exceptional, making the use of mercury more widespread than in underground mining (Figure 1b). They also point out that they have been trained by the environmental authorities on the cyanidation process, removing lack of knowledge as the reason why this method is not used instead of mercury amalgamation. Based on the information provided in the mining activities census, 57\% (2338) of Colombia's gold exploitation operations do not use mercury to extract the gold, while only $6 \%$ (263) of the mines recognize the use of this product (mainly in the department Bolivar). However, there is a void in the information provided by the census as $37 \%$ (1527) of the mines failed to provide relevant information on the subject.

Lastly, it is important to note that the high rates of illegal mining ( $87 \%$ without a mining title) influence the existence of high environmentalillegality (without environmental authorizations: environmental licenses, waste water discharge permits, forest resources use permit, water concessions or approved environmental management plan). According to the mining census, over $95 \%$ of the mines lack environmental authorizations (Table 2 ) and only 3\% have an environmental permit, an environmental management plan and a water concession permit.

Table 2. Environmental authorizations of gold mines in Colombia $(n=4134)$. Yes $=$ percentage of mines with environmental authorization. No $=$ percentage of mines without environmental authorization.

\begin{tabular}{|c|c|c|c|}
\hline Autorization & Type of mine & Yes $(\%)$ & No $(\%)$ \\
\hline Environmental & Legal & 2 & 11 \\
\hline License & Illegal & 1 & 86 \\
\hline \multirow{2}{*}{$\begin{array}{l}\text { Environmental } \\
\text { management plan }\end{array}$} & Legal & 2 & 11 \\
\hline & Illegal & 1 & 86 \\
\hline \multirow[t]{2}{*}{ Water concession } & Legal & 2 & 11 \\
\hline & Illegal & 1 & 86 \\
\hline \multirow{2}{*}{$\begin{array}{l}\text { Use of forest } \\
\text { resource }\end{array}$} & Legal & 0.6 & 13 \\
\hline & Illegal & 0.4 & 86 \\
\hline \multirow{2}{*}{$\begin{array}{l}\text { Wastewater } \\
\text { discharge }\end{array}$} & Legal & 1.7 & 12 \\
\hline & Illegal & 0.3 & 86 \\
\hline
\end{tabular}

The forest resource use permit is acquired by only 
$1 \%$ of mines and the wastewater discharge permit is acquired by only $2 \%$ of the gold mines. The latter is critical to manage the dumping of mercury into the environment. It is remarkable that the two essential requirements for mining are an environmental license and an environmental management plan; however, it was established that $90 \%$ of legal mining operations have neither.

Public policies and state management: Our review of existing applicable standards confirmed that the legal system restricts the use of mercury in legal and illegal gold mining. Regarding legal mining, Decree 2222 of 1993 prohibits the use of mercury for the procurement of gold unless technical studies deem it indispensable. Where authorized, the release of mercury into bodies of water is prohibited (art. 244); the use of mercury collection systems is mandatory in dredging washout plants (art. 295); miners are required to use hermetic retorts to reduce emissions of mercury vapors released by the roasting amalgam (art. 267); amalgamation activities must be conducted indoors (art. 293); and a contingency plan to prevent and handle any mercury spills that may occur must be implemented (art. 268). Lastly, Article 295 requires recovery and collection systems to not exceed the permissible limits of contamination.

From an environmental standpoint, it is worth noting that an environmental license is required to begin the stages of mining exploitation (Law 99 of 1993 art. 49, Decree 2820 of 2010 arts. 8 and 9). This license is issued once the appropriate environmental impact study is analyzed and approved; the study must adhere to the terms of reference provided by the environmental authorities (Law 99 of 1993 art. 57). However, the terms of reference for the exploitation of alluvial gold issued in 1998 by the Ministry of Environment (MMA) do not take into account aspects related to the use of mercury and despite requests since 2010, they have not been updated (Decree 2820 of 2010 art. 14). On the other hand the terms of reference for gold vein mining, although also issued in 1998, include requirements to identify and evaluate mercury vapors emitted and the pollution by mercury of water and soil (MMA 1998). It is worth mentioning that there is an environmental gold mining guide (MMA 1999) that examines the application of mercury and its consequences and also offers alternative methods to contribute to the reduction of pollution, however, this guide is not mandatory.

Whereas for illegal mining, any mining activity without the corresponding mining title is forbidden even by the provisions of criminal law (Penal Code art. 338) and its violation is punishable by fines of up to 50,000 minimum wages and up to 144 months in prison. Of course, this prohibition includes the process of beneficiation of minerals using mercury so its execution without due authorization by the mining authority carries a fine and the deprivation of liberty.

However, this criminal sanction has not impeded the high rates of illegal gold mining in Colombia, proving that the implemented legalization policies have not been as successful as hoped. The first indication of this, as mentioned, is that $87 \%$ of the existing gold mining operations in the country are illegal. Secondly, within the last 15 years, government has offered small miners three opportunities to legalize their operations through Laws 141 of 1994, 685 of 2001 and 1382 of 2010 . Seven years after the second opportunity (Law 685 of 2001), out of 3,631 applications submitted, only 23 mines were legalized, demonstrating an effectiveness of less than 1\% for the program (SIGOB 2007). Thirdly, the 2011 mining census confirmed that out of 9,041 illegal mines, only 382 are in a mining legalization program, this is equivalent to a total of only $4 \%$ within the legalization process. Fourthly, the municipalities with the highest gold mining tradition in the country (Pasto, Nariño; Cucunubá, Cundinamarca; La Uvita, Boyacá; Tunja, Boyacá; Yaruma, Segovia and Añuri, Antioquia) reported only 149 mines in the mining formalization process, a total figure similar to the previous. And lastly, according to the evaluation program implemented by Colombia's National Results-Based Management and Evaluation System (SINERGIA 2012) of the formalized small mining associations program, between July 2011 and October 2012 not a single small mining association was formalized in the country. Among the qualitative achievements of this formalized small mining associations program is the completion of five mining formalization sessions in the departments of Huila, Cundinamarca, 
Cordoba, Antioquia, Boyacá, mining roundtables in the departments of Chocó and Nariño, the implementation of a pilot program in the lower Cauca region of Antioquia, miner forums for indigenous communities in the Colombian Amazon in Guainía and Vaupés and finally the issuance of Decree 1970 of September 21, 2012 which redefines the mining authority's requirements of traditional miners to legalize their activity when working in mines without titles registered with the National Mining Registry that are state-owned. Notably, the most significant change in the most recent mining legalization process reform is that illegal miners are now allowed to apply for concessions in areas declared forest reserves, this is also allowed for large mining concessions. This proves that in some cases, the requirements for the legalization of artisanal miners are more demanding than those required for large mining concessions. The prohibition enforced on illegal miners to apply for mining concessions in forest reserve areas in the country eliminated for the majority, any possibility of formalizing since the areas deemed forest reserves in Colombia (Law 2 of 1959) occupy $45 \%$ of the national territory.

However, the reality of Colombia is that much of the area occupied by small miners overlaps with areas already under concession (Law 865 of 2001 art. 45). It is estimated that $90 \%$ of the areas are already under a concession agreement, limiting the possibility of effective legalization (Delgado 2012) given that mining legalization applications are outright rejected in areas under concession (Decree 1870 of 2012 art. 3). Similarly, negotiations mediated by the state authority in this matter (Law 1382 of 2010 art. 12, Decree 1870 of 2012 art. 8) do not require engaging into association or operation agreements, therefore, if a consensus is not reached, the opportunities for traditional miners to formalize their activities come to an end.

As a final point, the news probe yielded information regarding police operatives carried out during the mandate of current President Juan Manuel Santos (August 2010 - August 2014), which led to the closure, in 2010, of more than 56 illegal mines and the arrest of 573 people in 18 departments of Colombia mainly in Antioquia and Cordoba. In 2011, 329 gold mines were closed and 1,228 people were detained in 27 departments. Then in 2012, 536 mines were closed and 1,600 people were arrested mostly in the departments of Bolivar, Nariño, Tolima and Valle. No reports of operations conducted during the second term of President Álvaro Uribe Vélez (August 2006 - August 2010), were found in the media, which indicates that this policy of law enforcement used to control illegal mining was adopted during the current presidency.

Consequences on health and the environment: Table 3 lists several studies conducted in Colombia, which demonstrate mercury contamination in the environment and the consequent poisoning of residents and neighbors in areas where gold mining activities take place. In addition to the studies, this table lists the concentrations encountered, the natural resources affected and the geographic location for each of them. In the section dealing with mercury poisoning in humans, it identifies whether the sample used to test this was blood, urine or hair. Most studies related to mercury contamination have been conducted on fish; we can, therefore, confirm the presence of mercury in the water sources of the different regions studied.

These studies found mercury concentrations in the air up to a thousand times higher than allowed by the WHO (200ng/m3) (Cordy et al. 2011). In fish, mercury concentrations reached $1,08 \mu \mathrm{g} / \mathrm{g}$ in

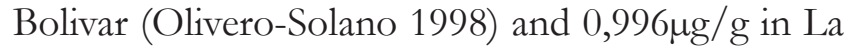
Mojana (Marrugo-Negrete et al. 2008), when the allowable concentrations are up to $0.5 \mu \mathrm{g} / \mathrm{g}$ (WHO 1991). Regarding poisoning in humans, MedinaMosquera et al. (2011) found that $80 \%$ of the study population had high concentrations of mercury in their blood $(38,52 \mu \mathrm{g} / \mathrm{L})$, urine $(141,97 \mu \mathrm{g} / \mathrm{L})$ and hair $(82,59 \mathrm{ppm})$, even with no risk limits of $10 \mu \mathrm{g} / \mathrm{L}$ for blood, $20 \mu / \mathrm{L}$ for urine and $5 \mathrm{ppm}$ for hair, according the the WHO (1991).

The studies on mercury contamination are mostly focused on the departments of Antioquia, Bolivar and Chocó. However, mercury contamination is also prevalent in other areas, such as the municipalities of Neiva, Girardot and some coastal marshes in the Caribbean (Table 3). Among the most polluted rivers are the San Jorge and the Cauca, as well as the Magdalena River marshes, which supply the departments with the highest number of illegal gold mines in the country. 
Table 3. Environmental impacts of mercury used in gold mining in Colombia. World Health Organization (WHO) permissible limits (1991): Water: $0.001 \mathrm{mg} / \mathrm{l}$, Fish $0.5 \mu \mathrm{g} / \mathrm{g}$, Blood $10 \mu \mathrm{g} / \mathrm{l}$, Urine $20 \mu \mathrm{g} / \mathrm{l}$, hair $5 \mathrm{ppm}$ and air $200 \mathrm{ng} / \mathrm{m}^{3}$.

\begin{tabular}{|c|c|c|c|c|c|c|c|c|}
\hline \multicolumn{9}{|c|}{ IMPACT } \\
\hline \multirow[b]{2}{*}{$\begin{array}{l}\text { Colombian } \\
\text { Department }\end{array}$} & \multirow[b]{2}{*}{$\underset{(\mathrm{ng} / \mathrm{m} 3)}{\operatorname{Air}}$} & \multirow[b]{2}{*}{$\begin{array}{l}\text { Water } \\
(\mu \mathrm{g} / \mathrm{l})\end{array}$} & \multirow[b]{2}{*}{$\begin{array}{l}\text { Plants } \\
(\mu \mathrm{g} / \mathrm{g})\end{array}$} & \multirow[b]{2}{*}{$\underset{(\mu \mathrm{g} / \mathrm{g})}{\text { Fish }}$} & \multicolumn{3}{|c|}{ Human } & \multirow[b]{2}{*}{ Reference } \\
\hline & & & & & $\begin{array}{l}\text { Blood } \\
(\mu \mathrm{g} / 1)\end{array}$ & $\begin{array}{l}\text { Urine } \\
(\mu \mathrm{g} / \mathrm{l})\end{array}$ & $\begin{array}{l}\text { Hair } \\
(\mathrm{ppm})\end{array}$ & \\
\hline Sucre & & & & $\begin{array}{c}0.116-0.602 \\
0.054-0.639 \\
0.041-0.669 \\
0.036-0.247 \\
0.073-0.996 \\
0.048-0.689 \\
0.035-0.207\end{array}$ & & & & $\begin{array}{l}\text { Marrugo-Negrete et } \\
\text { al. (2008) }\end{array}$ \\
\hline Chocó & & & & & $\begin{array}{l}0.60-15.73 \\
2.13 \\
8.05-19.29 \\
0.80-32.78 \\
1.64-2.61 \\
2.86-22.94 \\
1.97-38.52 \\
16.61 \\
0.76-14.27\end{array}$ & $\begin{array}{l}0.02-17.61 \\
1.38-3.12 \\
0.58-12.12 \\
8.50-25.94 \\
5.37 \\
10.95-29.46 \\
20.19- \\
111.51 \\
141.97 \\
9.44-44.92\end{array}$ & $\begin{array}{l}0.18-2.31 \\
0.10-1.28 \\
0.30-14.62 \\
19.65-79.32 \\
0.96 \\
0.87-76.29 \\
0.55-82.59 \\
48.69 \\
0.25-29.64\end{array}$ & $\begin{array}{l}\text { Medina-Mosquera et } \\
\text { al. (2011) }\end{array}$ \\
\hline Antioquia & $\begin{array}{l}10-60.000 \\
100-943.000 \\
40-80.000 \\
30-200.000\end{array}$ & & & & & & & Cordy et al. (2011) \\
\hline Bolívar & & & & & & & $\begin{array}{l}5.27 \\
2.44 \\
2.2 \\
0.9 \\
0.92 \\
0.94 \\
1.08 \\
1.57 \\
1.77 \\
1.24 \\
1.06 \\
1.09\end{array}$ & $\begin{array}{l}\text { Olivero-Verbel et al. } \\
\text { (2011) }\end{array}$ \\
\hline Sucre & & $\begin{array}{l}0.158-0.210 \\
0.075-0.198\end{array}$ & & & & & & $\begin{array}{l}\text { Olivero-Verbel et al. } \\
(2004)\end{array}$ \\
\hline Bolívar & & & & $0.01-0.56$ & & & $0.11-29.20$ & Olivero et al. (1995) \\
\hline Bolívar & & $0.14-0.39$ & $0.11-0.43$ & $0.011-1.08$ & & & & $\begin{array}{l}\text { Olivero \& Solano } \\
\text { (1998) }\end{array}$ \\
\hline $\begin{array}{l}\text { Antioquia } \\
\text { Caldas }\end{array}$ & & & & $\begin{array}{l}0.040-0.93 \\
0.008-0.092\end{array}$ & & & & Alvarez et al. (2012) \\
\hline $\begin{array}{l}\text { Sucre } \\
\text { Eight } \\
\text { departments }\end{array}$ & & & & $0.001-1.236$ & & & 4.91 & $\begin{array}{l}\text { Olivero et al. (2002) } \\
\text { Mancera-Rodríguez } \\
\text { \& Álvarez-León } \\
\text { (2006) }\end{array}$ \\
\hline
\end{tabular}




\section{Discussion}

Mining and environmental informality and illegality: According to research results, gold mining in Colombia is characterized as an illegal and small-scale, artisanal craft $(60 \%$ of the country's gold mining). This type of mining presents a unique opportunity for communities living in impoverished rural areas with indexes of poverty and indigence of about $60 \%$ by Colombian standards (United Nations 2010). By participating in these mining activities, workers from these impoverished communities can generate per capita income between U.S.\$500 and U.S. $\$ 3,000$ per month depending on the production of the mine. However, despite its social and economic importance, most mines operate outside of the legal framework and activities are carried out in areas under concession by third parties or devoid of any permits, and are frequently persecuted by law enforcement (Wotruba et al. 2000).

Small-scale gold mining is neither a recent nor local activity. Rather it is an activity that has existed since before the arrival of the Spanish to Latin America (West 1972) and its reach is worldwide (Siegel and Veiga 2009). The individuals carrying out this activity are called many names depending on the region. They are called pirquineros in Argentina and Chile (Decree No. 123 of 2001, art. 3) palliri, jukus, and barranquilleros in Bolivia, garimpeiros in Brazil (Garimpeiro Statute - Act 685 art. 2), barequeros and chatarreras (Figure 1d) in Colombia (Mining Code - Act 685 of 2001 s. 155), coligalleros in Costa Rica (Mining Code Regulations art. 4), jancheros in Ecuador (Pillajo 2003) gambusinos in Honduras and Mexico (Gonzalez-Sanchez and Camprubi 2010), lavadores de oro (gold washers) in the Dominican Republic and güiriseros in Nicaragua (Decree 119 of 2001 art. 56), to name a few. Also, they are called galamsey in several African countries (Bush 2009).

Despite its propagation and tradition, the concealment and illegality that surrounds smallscale gold mining activities makes understanding the dimension of its productivity and employment offerings complex. Internationally, the study conducted by the ILO (1999) stands out. The study estimates the number of workers in smallscale mining of all minerals and classifies them by countries as follows: Brazil 250,000, Colombia
200,000, Bolivia 100,000, Ecuador 60,000, Peru 50,000 Venezuela 40,000, Chile 12,000, Nicaragua 6000, Argentina 5800, Cuba 5000, Panama 4500 and the Dominican Republic 3000. The discrepancy in the results is obvious, according to the mining census the number of jobs generated by small scale gold mining in Colombia does not exceed 50,000 jobs; however, according to Cordy et al. (2011) this figure is around 200,000 (0.43\% of the Colombian population), making it clear that despite conducting a mining census in Colombia, we are still far from determining the actual numbers of jobs in this activity. The illegality of this large percentage of auriferous activities $(87 \%)$ in Colombia continues to be one of the principle reasons that exact numbers are unascertainable; the clandestine nature of the activities compel illegal miners to refrain from disclosing actual data, making the figures unrealistic.

If we compare the data compiled by the Ministry of Environment (2002) with the data from the 2011 mining census, it is evident that gold mining in Colombia has doubled in the last 10 years from 2,129 mines in 2002 to 4,134 mines in 2011. Although gold production and the number of gold mines increased by 100\% from 2002 (MMA 2002) to 2011 (2011 mining census), the geographical distribution of gold mining in Colombia is virtually unchanged (Figure 2). This means that the natural resources and human populations impacted by the activity have continued to be the same for the past 10 years, even though the magnitude of contributions of contaminants may have doubled, among these, the use of mercury.

Not having secured the rights over the minerals, small gold miners are exposed to being evicted or invaded. Their productions may be confiscated or they may be subjected to extreme conditions to carry out their work, some even having to endure the abuse of processors, traders and corrupt officials (Mosquera 2005). This persecution by public authorities and the marginalization resulting from difficult economic conditions may also prevent them from participating in policies relating to their working and living conditions (Tschakert 2009). It was determined that small gold miners in the Colombian municipalities of Suarez and Remedios, are sporadically extorted by groups outside the law to be allowed to perform the activities vital in 
obtaining their subsistence. In view of this legal uncertainty, the persecution of the authorities, the precarious economic conditions and non participation in decisions that affect them directly, gold miners prefer to use products like mercury in the amalgamation of gold instead of using techniques requiring greater investments of time and money such as cyanidation.

Consequence of this informality, 95\% of all the gold mines in the country have no environmental authorizations, which points to the authorities responsible for the environmental protection of the country who, obviously, consider almost none of the gold exploitation operations in the country sustainable. In other words, according to environmental institutions, only $5 \%$ of all Colombian gold meets environmental principles.

The dilemma is that most gold mining is illegal and tens of thousands of rural families have depended on it for decades for their livelihood. Therefore, one viable solution, from an environmental and social standpoint, is the formalization of the activity in order to restrict the use of mercury and improve mining practices and in this way inflict less potential impacts on the environment.

Public policy and state management: in an effort to address the informality and illegality of mining activities, government has adopted different strategic guidelines and policies, all with little success. On the one hand, there are those conceived from a strategy designed to support subsistence, a policy against poverty following a welfare guideline, but without recognizing the activity. This has been an issue in many regions like the municipalities of Taraira (Vaupés department) and Buenos Aires and Suárez (Cauca department) where small gold miners have been given mining supplies and machinery but not the recognition of their legality. The artisanal miners in these particular municipalities have denounced that after being given machinery and equipment for mining by the government the concession of the mining areas were issued to foreign companies.

A second form of government action against the issue of illegal mining is to seek its eradication without consideration for the communities that engage in this activity because they have no other means of livelihood. As mentioned before, since the beginning of the current President Juan Manuel Santos's presidency, the persecution by law enforcement has led to the closure of 921 gold mines and the incarceration of more than 3,400 artisanal miners.

However, the most suitable solution, given the high rates of illegality and social impacts associated with this activity, is through policies that seek to incorporate informal labor into legitimacy with the protection and promotion of the state; policies that recognize the activity as a means of sustenance for a sector that has been marginalized from institutionalism for years and implement mining formalization processes that are sensible to the socioeconomic conditions of the miners. As mentioned earlier, so far in Colombia the formalization of these processes has not had significant success, partly because of the demanding requirements placed upon small miners and because many of the areas have been licensed to major miners long after the first miners began their activities in these locations.

It is clear that regulations alone will not create formal jobs in dignified conditions. An important social investment in gold mining regions is necessary, as well as formalization strategies that distinguish in favor of small-scale miners and dismiss any approximation with large-scale mining when obtaining environmental and mining permits. In addition, for this legislation to have legitimacy, it must be participatory and adapt to a social consensus and the reality of these miners (Veiga and Siegel 2009). Miners in Colombia have not been involved in the creation and implementation of these regulations and this has been a major cause of the failure of these programs. As mentioned by Siegel and Veiga (2009), the formalization process has failed mainly due to the unwillingness of governments to implement these policies and the inability of miners to afford the process and to fulfill the demanding requirements necessary to obtain environment licenses. Idárraga et al. (2010) have documented the main cause for this breakdown, specifically in the case of Colombia, is the difficulty to obtain environmental permits and licenses, given that the requirements imposed upon small miners by the Mining Code and environmental laws are the same requirements as those required from large mining concessions. 
Furthermore, these programs to formalize mining should be bolder in settling overlap issues between traditional mining (Law 1382 of 2010 art. 12) and the areas concessioned to large mining companies. When you consider that nearly 90\% of the areas in which illegal mining occurs are areas already under concession, it is clear that if government does not interfere in these cases with more than simple mediation (Decree 1870 of 2012 art. 8), illegal mining will persist in the country for many years to come. One solution would be to require large mining operations to cede part of their lands under concession to be used for small-scale artisanal gold mining.

To conclude, if gold production in the country continues to increase and we disregard the formalization of the mining processes, the impacts generated by the increased use of mercury in this activity will be catastrophic. The legalization and formalization of small-scale gold mining enables the structuring of environmental management plans and facilitates the effective control by environmental authorities (Güiza 2008). This will result in the mitigation of environmental damages and the compliance with environmental regulations, such as the restriction on the release of mercury wastewater into water sources (Decree 2222 of 1993 art. 244) and the use of mercury only when it is necessary and after evaluating other alternatives (Decree 2222 of 1993 art. 293).

\section{Consequences on health and the environment:} As previously mentioned, $72 \%$ of all the gold mines in Colombia are located in the northeast and along the Cordillera Occidental (western mountain range), mainly in the departments of Antioquia, Bolivar and Chocó. They are mostly small-scale, untitled mines, constructed rudimentarily and devoid of any type of environmental authorizations, making them potential mercury users in the amalgamation process and the beneficiation of gold and responsible for the consequent environmental impacts the use of this product generates (Telmer and Veiga 2009). Coincidentally, studies conducted in Colombia on mercury contamination were carried out in these same areas and on the watersheds that irrigate them (Table 3). The results of these studies confirmed serious effects of mercury in the air (Cordy et al.
2011), in water resources (Olivero-Verbel et al. 2004), in fish (Mancera-Rodriguez and AlvarezLeon 2006) and in humans (Medina-Mosquera et al. 2011, Olivero-Verbel et al. 2011).

We have previously stated that artisanal miners prefer the use of mercury because it is inexpensive, easy to use and quick to separate the gold from gold bearing materials. Despite that, we only identified with certainty that $6 \%$ of gold mines use mercury in the gold beneficiation process; however, another $37 \%$ of the mines withheld this information, probably because the miners are aware of the prohibitions and the impacts on the environment and on health surrounding the use of mercury. This is apparent in towns like Segovia (Antioquia) where according to the 2011 mining census, there are 167 gold mines and the annual reported sales of mercury in the municipality was 18 tons (Cordy et al. 2011), yet none of the mines reported information regarding the use of mercury in their mining activities. In addition, we believe that given the stigmatization associated with the use of mercury, many of the miners who denied its use in their activities (57\%) may very well be using it. Our hypothesis on the widespread use of mercury in informal mining is also based on the fact that Colombia is among the largest importers of mercury (Telmer and Veiga 2009) and it is one of the countries most contaminated by this product (Cordy et al. 2011). Accordingly, we also conclude that the majority of illegal small-scale miners, which represent $60 \%$ of the country's gold exploitation, are using mercury in their gold beneficiation process.

In view of the high environmental illegality and the widespread use of mercury, studies confirm the high concentrations of this product in humans, wildlife, and the air (Table 3). This proves that despite the environmental damage, environmental authorities have been weak in controlling these impacts. As it is not only the mines operating without a mining title, but between $11 \%$ and $13 \%$ of the mines with a mining title that have no environmental license or authorization to pursue an activity that increases the chances of mercury use and its improper disposal, emission or discharge into the environment. 


\section{Conclusion}

The causes generating the high levels of mercury consumption in gold mining activities in Colombia are: $87 \%$ of gold mining in Colombia is practiced illegally; mining formalization policies have been ineffective and in some cases require the same or greater requirements of small-scale miners as of large mining concessions; only $3 \%$ of gold mines have environmental license, which is required to carry out the activity; miners prefer the use of mercury because the technique is easier, faster and cheaper for the separation of gold; government persecution by police operatives make everyday activities more clandestine for miners and thus make them take greater risks to cut down on ore production times, which encourages the use of mercury; there is no control on the procurement of mercury, which has positioned the country as the world's second largest importer. The consequences on the environment and human health have not been sufficiently documented in the country. However, in the few studies conducted in Colombia there is evidence that exceeds the maximum allowable limits in both humans and fish air.

\section{Acknowledgements}

This article was supported by the Office of the Ombudsman, the Delegate Ombudsman for Collective Rights and the Environment and Delegate Ombudsman Mayibe Ardila Ariza. We thank the Universidad del Rosario's undergraduate Jurisprudence students ascribed to the Mining and Human Rights line of investigation for their insights and support in the research. Lastly, we express our gratitude to Enrique Castro Rincón, representative of the gold miners in the municipality of Taraira (Vaupés) for his special support. The authors report no conflict of interest in the publication of this information.

\section{References}

Ali SH (2006) Gold mining and the golden rule: a challenge for producers and consumers in developing countries. Journal of Cleaner Production 14(3-4):455462

Álvarez S, Jessick A, Palacio J, Kolok A (2012) Methylmercury Concentrations in Six Fish Species from Two Colombian Rivers. Bulletin of Environmental
Contamination and Toxicology 88:65-68

British Geological Survey (2012) World mineral production 2006-2010 Keyworth, Nottingham British Geological Survey, London

Bush R (2009) Soon there will be no-one left to take the corpses to the morgue: Accumulation and abjection in ghana's mining communities. Resources Policy 34(12): $57-63$

Castilhos CZ, Rodrigues-Filho S, Rodrigues AP, VillasBoas RC, Siegel S, Veiga MM (2006) Mercury contamination in fish from gold mining areas in Indonesia and human health risk assessment. Science of the Total Environment 368: 320-325

Chaparro E (2002) Actualización de la compilación de leyes mineras de catorce países de América Latina y el Caribe Volumen II. CEPAL División de Recursos Naturales e Infraestructura, Santiago de Chile, Chile

Cordy P, Veiga MM, Salih I, Al-Saadi S, Console S, Garcia O, Mesa L, Velásquez-López P, Roeser M (2011) Mercury contamination from artisanal gold mining in Antioquia, Colombia: The world's highest per capita mercury pollution. Science of the total Environmente 410:154-160

Delgado A (2012) Revista Cien días No. 76. Disponible en: http://www.cinep.org.co/archivoscinep/Ciendias_76_pdfs/13.pequenaygranmineria.ciendias76.pdf (consultada el 24 de noviembre de 2012)

EPA (2007) Inorganic Mercury Teach Chemical Summary Disponible en: http://www.epa.gov/ teach/chem_summ/mercury_inorg_summary.pdf (Consultado 12 enero 2013)

Fisher E, Mwaipopo R, Mutagwaba W, Nyange D, Yaron G (2009) The ladder that sends us to wealth: Artisanal mining and poverty reduction in Tanzania. Resources Policy 34(1-2): 32-38

Gonzalez-Sánchez F, Camprubi A (2010) La pequeña minería en México. Boletín de la Sociedad Geológica Mexicana 62 (1):100-108

Güiza L (2008) Efectividad de los instrumentos administrativos de sanción y exigencia de la reparación del daño ambiental en Colombia. Revista Estudios SocioJurídicos 10(1): 307-335

Güiza L (2010) La Minería de Hecho en Colombia. Defensoría del Pueblo, Bogotá, Colombia. Disponible en: http://www.defensoria.org.co/red/anexos/publicaciones/mineriaColombia.pdf.

Güiza L (2011) Perspectiva jurídica de los impactos ambientales sobre los recursos hídricos provocados por la minería en Colombia. Opinión Jurídica 10 (1): 123140

Hilson G, Pardie S (2006) Mercury: an agent of poverty in Ghana's small-scale gold mining industry? Resources Policy 31 (2):106-116

Hinton J, Veiga MM, Veiga AT (2003) Clean artisanal gold mining: a utopian approach? Journal of Cleaner Production 11:99-115 
Idarraga F, Muñoz DA, Vélez H (2010) Conflictos socioambientales por la extracción minera en Colombia http://www.censat.org/censat/pagemaster/ 0qmgpfuh9zfaaghwnzahryo2ahvq1w.pdf (consultado mayo del 2012)

International Institute for Environment and Development (IIED) World Business Council for Sustainable Development (2002) Minería Artesanal y en Pequeña Escala. En: Abriendo brecha: minería, y desarrollo sustentable, Londres, Inglaterra.

Liu G, Cai Y, O’Driscoll N, Feng X, Jiang G (2012) Overview of Mercury in the Environment. In Liu G, Cai Y, O'Driscoll N (eds) Environmental Chemistry and Toxicology of Mercury First Edition, pp 1-12

Logsdon MJ, Hagelstein K, Mudder T (2001) El Manejo del Cianuro en la Extracción de Oro. Traducido de la publicación en inglés titulada The Management of Cyanide in Gold Extraction. Ana María Paonessa (trad). The International Council on Metals and the Environment, Ottawa, Canada

Mancera-Rodríguez N, Álvarez-León R (2006) Estado del conocimiento de las concentraciones de mercurio $\mathrm{y}$ otros metales pesados en peces dulceacuícolas de Colombia. Acta Biológica Colombiana 11(1):3-23

Marrugo-Negrete J, Benitez L, Olivero-Verbel J (2008) Distribution of Mercury in Several Environmental Compartments in an Aquatic Ecosystem Impacted by Gold Mining in Northern Colombia. Archives of Environmental Contamination and Toxicology 55:305316

Marrugo-Negrete J, Olivero-Verbel J, Lans E, Benitez L (2008) Total mercury and methylmercury concentrations in fish from the Mojana region of Colombia. Environmental Geochemestry and Health 30:21-30

Medina-Mosquera F, Ayala-Mosquera H, Perea J (2011) Determinación de la contaminación mercurial en personas vinculadas con la minería de oro en el Distrito Minero del San Juan, departamento del Chocó, Colombia. Bioetnia 8 (2):195-206

Ministerio del Medio Ambiente (MMA) (1998) Términos de referencia para la explotación de oro, Bogotá, Colombia

Ministerio del Medio Ambiente (MMA) (1999) Guía ambiental para la pequeña y mediana minería del oro -MMA/CENSAT/AGUA VIVA, Bogotá Colombia

Ministerio del Medio Ambiente (MMA) (2002) Diagnóstico y proyecciones de la gestión minero ambiental para las regiones auríferas de Colombia. Bogotá, Colombia

Mosquera-Lozano Y, Torres-Ibarguen A, LozanoLargacha Y, Pereamena B (2005) Incidencia del mercurio por la explotación minera en algunas especies de peces en el río Condoto, Chocó-Colombia. En: Memorias del VIII Simposio Colombiano de Ictiología. ACICTIOS/UTCH, Quibdó, Colombia
Naciones Unidas (2010) La hora de la igualdad: brechas por cerrar, caminos por abrir. CEPAL, Santiago de Chile, Chile

Olivero J, Johnson B, Arguello E (2002) Human exposure to mercury in San Jorge river basin, Colombia, South America. Science of the Total Environment 289:41-47

Olivero J, Mendonza C, Mestre J (1995) Mercurio en cabello de diferentes grupos ocupacionales en una zona de minería aurífera en el Norte de Colombia. Revista de Saúde Pública 29 (5):376-379

Olivero J, Solano B (1998) Mercury in environmental samples from a waterbody contaminated by gold mining in Colombia, South America. Science of the Total Environment 217:83-89

Olivero-Verbel J, Caballero-Gallardo K, NegreteMarrugo J (2011) Relationship Between Localization of Gold Mining Areas and Hair Mercury Levels in People from Bolivar, North of Colombia. Biological Trace Element Research 144:118-132

Olivero-Verbel J, Johnson-Restrepo B, Mendoza-Marin C, Paz-Martinez R, Olivero-Verbel R (2004) Mercury in the aquatic environment of the village of Caimito at the mojana region, north of Colombia. Water, Air, and Soil Pollution 159:409-420

Organización Internacional del Trabajo -OIT- (1999) Los problemas sociales y laborales en las explotaciones mineras pequeñas, Ginebra, Suiza

Osores F, Grándes A, Fernández J (2010) Mercurio y salud en Madre de Dios, Perú. Acta Medica Peruana 27 (4):310-314

Pillajo E (2003) Caracterización de la pequeña minería aurífera en ecuador y propuestas para su reactivación. En: Villas-Bôas RC y Aranibar, AM (Eds.) Pequeña Minería y Minería Artesanal en Iberoamérica: Conflictos, Ordenamiento, Soluciones. CETEM/ CYTED/CONACYT. Rio de Janeiro, Brasil

Pirrone N, Cinnirella S, Feng X, Finkelman RB, Friedli HR, Leaner J, Mason R, Mukherjee AB, Stracher G, Streets DG, Telmer K (2009) Global Mercury Emissions to the Atmosphere from Natural and Anthropogenic Sources. In Pirrone N, Mason R (eds) Mercury Fate and Transport in the Global Atmosphere. Springer, NY, USA, pp 3-49

Programa de las Naciones Unidas para el Medio Ambiente - PNUMA (2005). Evaluación mundial sobre el mercurio. PNUMA. Disponible en: http:// www.chem.unep.ch/mercury/GMA\%20in\%20F\%20 and\%20S/final-assessment-report-Nov05-Spanish. pdf (Consultado 10 de enero de 2013)

Siegel S, Veiga MM (2009) Artisanal and small-scale mining as an extralegal economy: De soto and the redefinition of "formalization". Resources Policy 34(12):51-56

Sistema de Gestión y Seguimiento a las Metas del Gobierno -SIGOB- (2007) Programa de Legalización de Minas. Departamento Nacional de Planeación. Dis- 
ponible en: http://www.sigob.gov.co/met/meta.info. aspx? $m=122$ (Consultado el 4 de octubre de 2012)

Sistema Nacional de Evaluación de Gestión y Resultados -SINERGIA- (2012) Programa de Pequeñas asociaciones mineras formalizadas. Departamento Nacional de Planeación. Disponible en: https://sinergia.dnp. gov.co/portaldnp/default.aspx. (Consultado el 26 de noviembre de 2012).

Sousa RN, Veiga MM (2007) Final report on the Global Mercury Project in Brazil. UNIDO - United Nations Industrial Development Organization, Brazil

Sousa RN, Veiga MM, Klein B, Telmer K, Gunson AJ, Bernaudat L (2010) Strategies for reducing the environmental impact of reprocessing mercurycontaminated tailings in the artisanal and small-scale gold mining sector: insights from Tapajos River Basin, Brazil. Journal of Cleaner Production 18:1757-1766

Telmer K, Stapper D (2007) Evaluating and Monitoring Small Scale Gold Mining and Mercury Use: Building a Knowledge-base with Satellite Imagery and Field Work UNDP/GEF/UNIDO Project EG/GLO/01/ G34 Final Report

Telmer K, Veiga MM (2009) World Emissions of Mercury from Artisanal and Small Scale Gold Mining In Pirrone N, Mason R (eds) Mercury Fate and Transport in the Global Atmosphere. Springer, New York, USA, pp 131-172
Tschakert P (2009) Recognizing and nurturing artisanal mining as a viable livelihood. Resources Policy 34 (12):24-31

Unidad de Planeación Minero Energética _UPME(2007) Producción más limpia en la minería del oro en Colombia. Mercurio, cianuro y otras sustancias. Bogotá, Colombia

Veiga MM (1997) Introducing New Technologies for Abatement of Global Mercury Pollution in Latin America: Rio de Janeiro. UNIDO/UBC/CETEM/ $\mathrm{CNPq}$

Veiga MM, Maxson P, Hylander LD (2006) Origin of mercury in artisanal and small-scale gold mining. Journal of Cleaner Production 14:436-447

Veiga MM, Nunes D, Kleins B, Shandro J, Velazquez C, Sousa R (2009) Mill leaching: a viable substitute for mercury amalgamation in the artisanal gold mining sector. Journal of Cleaner production 17:1373-1381

West RC (1972) La minería de Aluvión en Colombia durante el periodo colonial. Melo Jorge (trad.) Imprenta Nacional, Bogotá, Colombia

WHO Environmental Health Criteria 101 (IPCS) (1991) Methylmercury. World Health Organization Geneva, Italy

Wotruba H, Hentschel T, Hruschka F, Priester M (2000) Manejo ambiental en la pequeña minería. Edición online: Gama - Cosude, Lima, Perú 